\title{
Upset Recovery Training In Collegiate Flight Programs
}

\author{
Brian G. Dillman and David L. Stanley \\ Purdue University \\ West Lafayette, Indiana
}

\begin{abstract}
Loss of control in flight has been a factor in a number of aircraft accidents in both commercial and general aviation. Although the frequency with which these accidents occur is small, the results are often fatal in nature. Both the aviation industry and regulating bodie s have seen the trends in accident statistics and support the inclusion of training for pilots in the skills necessary to handle these occurrences. Upset recovery training provides the skills necessary to recognize and recover from critical flight situations that can occur.
\end{abstract}

\section{INTRODUCTION}

As professional aviation educators our job is multilayered. We are required to assist students in the development of skills to the level mandated by the Federal Aviation Administration (FAA) pilot certification. We are also required to expose the students to any possible situation that may occur during their careers as professional pilots, regardless of how remote the possibility. Finally, our job as educators is to prepare our graduates so that they are marketable in the aviation industry.

It is a fine line between what the FAA requires for an applicant to pass a practical test and preparing that applicant for events that may occur in the foreseeable future. Upset recovery training fits within this fine line. The FAA requires unusual attitudes to be completed on many of the practical tests for pilot certification, but upset recovery training is not required for initial or recurrent certification for any pilot certificate.

An aircraft upset, as an industry standard, is defined as pitch attitudes greater than $25^{\circ}$ nose up, $10^{\circ}$ nose down, bank angles greater than $45^{\circ}$, or within the above parameters, but flying at airspeeds inappropriate for the conditions. (Boeing, 1998) While these numbers are routinely obtained and in some cases exceeded in general aviation, the fact that we are training the professional aviators of the future makes it imperative that they are fully aware of this industry standard. For the purposes of this paper, aircraft upsets are defined as pitch attitudes greater than $30^{\circ}$ nose up or down, or bank angles greater than $60^{\circ}$. The difference in the aircraft upset standard for this paper as compared to the industry standard is due to the difference in utility, normal and transport category aircraft.

The purpose of this paper will be to determine the extent to which collegiate aviation programs are offering or mandating upset recovery training in their curriculum. Further analysis will be used to determine the scope of this training and the stage at which it is completed.

\section{PAST ACCIDENTS}

The prevention of aircraft upsets does not receive the same amount of attention from the FAA that other causes of accidents receive because they are not often the root cause and are not as clearly defined. Regardless of this fact, when an aircraft upset occurs, resulting in an accident, the conclusion is often catastrophic. From 1987 to 1996 there were 37 in-flight loss of control accidents in transport aircraft, which resulted in over 2200 fatalities. (Airplane Safety Engineering, 1997) This put loss of control accidents as the second highest cause of airline fatalities worldwide from 1987 to 1996 (Figure $1)$. 
Figure 1

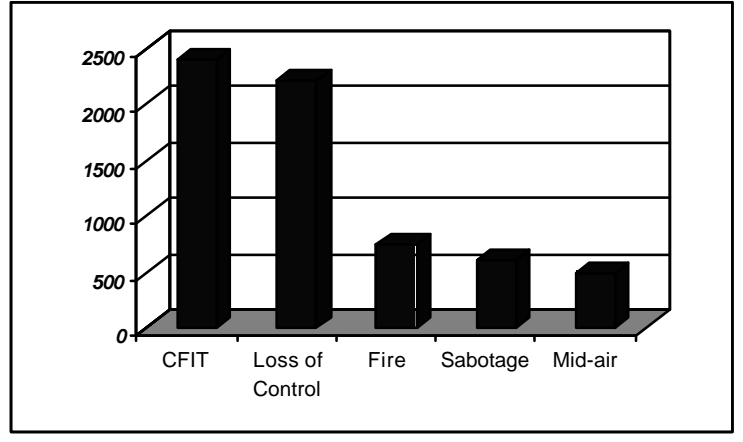

General aviation did not fare much better with respect to loss of control accidents. In 2000, loss of control accidents were the third leading cause with 25 , preceded by visual flight (VFR) into instrument meteorological conditions (IMC) with 32, and controlled flight into terrain (CFIT) with 27 (Figure 2). (AOPA, 2001)

Figure 2

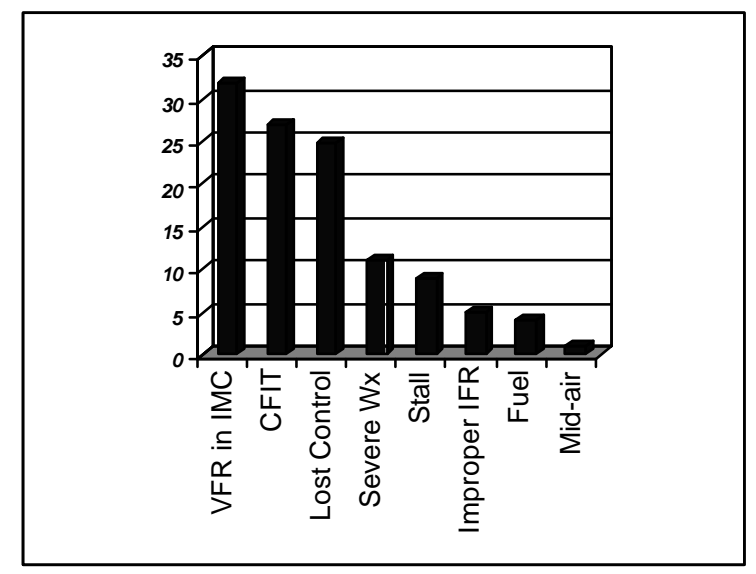

These numbers are significant and attention needs to be brought to these issues.

There are numerous examples from the National Transportation Safety Board and the Flight Safety Foundation of aviation accidents with aircraft upset as a root cause. In each instance there are varying circumstances surrounding the events leading up to the accident and varying levels of training received by each crewmember. For those accidents involving the omission of upset recovery training it is possible that the accidents might have been prevented if the crew had experienced upset recovery scenarios during initial or recurrent training.

There are also some accidents that occurred regardless of the fact that the crew had received upset recovery training within recent certification flights. It is important to note that even the best efforts of instructors and safety personnel to equip aviation professionals for all possible situations sometimes fail to meet the task at hand. Pilots are still involved in accidents stemming from skills that should have been acquired during private pilot flight training. In the case of upset recovery training, it is better to equip the aviation professional with all available tools for success and then have them fail, rather than send them forward and hope that they can recover on their own. The following are several accident scenarios to highlight the NTSB findings and how the accidents might have been prevented.

February 15, 1992, a DC-8 freighter on approach in instrument meteorological conditions to the Toledo Express Airport entered a steep bank and pitched nose down, resulting in the aircraft crashing 26 seconds later, killing the crew and one passenger. (Flight Safety Foundation, 1993)

A U.S. National Transportation Safety Board (NTSB) investigation report concluded that the probable cause of the accident was the "failure of the flight crew to properly recognize or recover in a timely manner from [an] unusual aircraft attitude. The NTSB said the unusual attitude could have resulted from a spatial disorientation experienced by the captain [who took control of the aircraft during climbout from the second missed approach], caused by either physiological factors or a failed attitude director indicator. About five seconds after the captain took control, shortly after the first officer acknowledged the turn to 300 degrees; the Flight Data Recorder (FDR) showed that the turn rate increased dramatically. Simulations, the NTSB said, showed that the bank angle then steepened to about 25 degrees when the captain said the words "what's the matter?", and a flight-path study indicated that eight seconds after exceeding 30-degrees bank angle, the airplane was passing through about 60-degrees left bank at a 14-degree descent angle, the report said. The first officer assumed control and began leveling the wings and raising the nose of the airplane, but the impact with the ground 
occurred before the unusual attitude recovery was complete.

This combination of steady, sustained turning, acceleration-to-deceleration changeover, and abrupt ascent to descent transition, at night with no visible horizon or outside references, is especially conducive to spatial disorientation.

The NTSB also concluded that the first officer's response to the captain's release of control was immediate and correct in execution, but a more aggressive control input may also have averted disaster. "Airline pilots are not periodically trained to recover from unusual attitudes as are military pilots or civilian acrobatic pilots," the NTSB said. "The presumption is that an airline pilot should avoid an unusual attitude and will never have a need to recover from one."

This accident is a textbook case of the flight crew not having the necessary training to deal with the situation at hand. In this accident the flight crew properly recognized they were in an upset situation, but due to a lack of experience they were not aware of how much control deflection should or could be applied to recover to straight and level flight. The NTSB summed it up when they stated that the accident underscored the need for further improvement in unusual attitude recovery and CRM training.

Obviously the crew was highly qualified to operate the aircraft and they had sufficient training in normal and abnormal operations but they inadvertently let the airplane get into an upset situation. That, in and of itself, is not the main point of this accident, but the main focus is the failure to properly respond to the upset situation.

November 11, 1998, a Saab 340 entering a holding pattern in instrument meteorological conditions at 15,000 feet over Eildon Weir, Australia had the autopilot disconnect, airplane roll left and descend 2300 feet before the flight crew regained control. (Flight Safety Foundation, 2001)

Upon entering the hold the airspeed deteriorated due to an accumulation of ice until the airspeed reached 136 knots. At this point the airplane stalled and rapidly rolled left to a bank angle of $127^{\circ}$ and pitched $36^{\circ}$ nose down. The first officer initially started the recovery, but the captain took control of the aircraft and recovered it to normal flight. During their Saab 340 transition training, both pilots received flight training in an airplane to recognize and recover from stalls, and to recover from unusual airplane attitudes. At the time of recurrent training the company's simulator-training program included stall recognition-and-recovery training but not unusualattitude-recovery training. Nevertheless, training captains were allowed to use time remaining at the completion of scheduled simulator training sessions to conduct exercises requested by pilots. The captain of the incident airplane had practiced unusualattitude recovery in the simulator; both pilots had practiced stall recovery in the simulator. The airplane operating manual (AOM) and the aircraft flight manual (AFM) did not contain information on recovering from unusual attitudes.

Despite the fact that the simulator training program and the operating manuals did not address upset recovery training, the captain took it upon himself to gain exposure to these flight situations. The experience he gained from these maneuvers may have allowed him to remain focused during the event and return the airplane to straight and level flight. During the transition training the first officer did not practice unusual attitude recovery; whether he would have been able to recover the airplane given enough time is uncertain. Had the captain not pursued upset recovery training on his own initiative the flight might have turned out very differently.

There are cases in which the flight crew makes the correct situational assessment and the necessary control inputs to recover despite never having experienced upset recovery training. Such was the case in the following accident report. April 29, 1993, an Embraer EMB-120 RT Brasilia entered an unusual attitude while climbing to Flight Level (FL) 220 in which one flight attendant and twelve passengers received minor injuries. (Lawton, 1994)

The crew was climbing to an assigned cruising altitude of FL 220 when the airplane stalled and went out of control. The airplane lost 12,000 feet of altitude before the flight crew regained control. Within 7 seconds of the stick shaker onset, the airplane developed a high rate of descent that reached in excess of 17,000 
[FPM (5,182 meters per minute)] during which the roll oscillations continued. Roll oscillations as high as 90 degrees in each direction and pitch attitudes as low as $67^{\circ}$ airplane nose down were recorded during the descent. Coincident with the roll oscillations, the airspeed reached about $210 \mathrm{KIAS}$, and the airplane, while remaining near a stall condition, developed a positive load factor between 2 and 3 Gs. The airplane finally recovered from the out-of-control descent when control forces were relaxed and the landing gear was lowered.

Whether the recovery from this accident was due to luck, experience, or a little bit of both, the NTSB nevertheless concluded that "this accident illustrates the need to emphasize to pilots the aerodynamic fundamentals of a stall-induced loss of control and the need to move the control column to reduce the angle of attack to recover from such a loss of control." The NTSB's recommendation clearly shows that upset recovery is a concern that must be addressed.

\section{INDUSTRY SUPPORT}

There is widespread support for upset recovery training throughout industry and government, and numerous companies and agencies made statements supporting efforts in upset recovery training with extreme unusual attitudes. Starting in June of 1996, a task force of 35 industry organizations participated in a series of five meetings and two review cycles in a collaborative effort to produce the Airplane Recovery Training Aid (Boeing, 1998). This training aid set the standard for recovery from aircraft upsets upon which numerous organizations have based their training program. In a statement on the Boeing website, Airbus and Boeing encourage all operators to endorse and include airplane upset recovery training (Boeing, 1998). Aircraft manufacturers have worked with operators to try and improve the safety record of aircraft such that the aviation industry and companies involved within that industry have a proven track record when it comes to aircraft accidents. Realizing that upset recovery training can reduce accidents, USAIG, the insurance company, has approved the aircraft maneuvers training (AMT) course at Texas Air
Aces as one of the follow-up recurrency programs its clients may take for credit toward better rates (Marsh, 1999). Another training program, offered by Chandler Air Service in Chandler, AZ, trains FBI pilots in their 10 hour upset recovery training program (Marsh, 1999).

Pilot organizations, including the National Business Aviation Association (NBAA) and the Air Line Pilots Association (ALPA), have voiced their concern with regard to training pilots in upset recovery. ALPA believes that the stall training mandated by the FAA does not adequately equip an airman to successfully recover from an event with an aerodynamically stalled or "performance degraded wing" (Air Line Pilots Association, 1998). ALPA goes on to state that the FAA should require training in recognition and recovery from ice-induced roll upsets or other aerodynamically degraded conditions (Air Line Pilots Association, 1998). Pilots, along with ALPA, state that upset recovery training is a necessity for the safe operation of an aircraft and it would be prudent for the FAA to revisit the requirements of pilot training. The NBAA Safety Committee voices its agreement in the NBAA Management Guide with the statement that turbulence/upset training is one of the best practices, one that will provide the highest margin of return for the investment in safety training (Sands, 1999).

Some consensus exists that there is a definite need for upset recovery training for aviation professionals; what remains is to determine who should provide the training. The purpose of this paper is not to determine where this responsibility lies, but to determine what is being done in collegiate flight programs.

\section{METHOD}

The authors developed a telephone survey (Purdue University, 2003) to assess the current status of upset recovery training in college flight training programs. The survey was designed to determine the current and proposed methods of upset recovery training in each flight program and to use the results to foster dialogue between institutions to determine the most effective method of upset recovery training. The phone survey was conducted 
during the spring of 2003. Four-year collegiate schools with flight programs were contacted and asked to complete the survey. Some two-year collegiate institutions also conduct upset recovery training, but to keep the sample size reasonable and to assure a high response rate, the 42 four-year collegiate schools listed in the University Aviation Association's Collegiate Aviation Guide (1999) were contacted. The authors were able to obtain survey information from 30 schools, which is a response rate of $71 \%$.

\section{SURVEY RESULTS}

The first question asked if the flight program is providing upset recovery flight training defined by pitch attitudes in excess of $30^{\circ}$ nose high or nose low or bank angles in excess of $60^{\circ}$. Of the schools that were contacted, $9(30 \%)$ stated that they did have a program in place to provide this flight training and $21(70 \%)$ stated that they did not have a program for upset recovery training. Of the schools that stated that they did not have a program two of them stated that they were looking into the possibility of starting a flight program for upset recovery training in the near future.

Of the schools that did have a program in place for upset recovery training several more questions were asked to determine the extent and the requirement of the students for the training. The next question asked whether the training was mandated for all flight students, of which 4 $(44 \%)$ stated that it was a requirement. Of those schools that did not mandate the training, time requirements and student cost were stated as the major reasons.

The type of aircraft used in each of the programs was determined to be widespread. Aircraft such as Super Decathalons, Aerobatic Bonanzas, Citabrias, Cessna 150 Aerobats, DeHavilland Chipmunks, Extra 300s, Cap 10s, and Great Lakes bi-wing aircraft were used. Several of the aircraft listed were being used because that was the aircraft that the school owned or could readily acquire when the decision was made to develop an upset recovery or aerobatic program. Of the schools that were able to select their aircraft, cost and availability of the aircraft as well as the ease of operation were quoted as the reasons for the selection.

The selection requirement for instructors that complete the upset recovery training was also determined. In every program, the selection process started with determining which instructors would be interested in teaching in such a program. Flying an airplane in these types of attitudes on a weekly, if not daily, basis is not for every instructor, so finding those that have a natural interest is the first step. After determining those that are interested, a hierarchy of qualifications such as seniority, past training, experience, and overall piloting skill were assessed to make the final determination.

An attempt to determine the deficiencies in the upset recovery programs was made by asking what was disliked about the program or, if possible, what would be changed. The answers to this question were widespread and included items such as making the training mandatory (for those for which it was not mandatory), making the training more in-depth or more extensive, focusing more on upset recovery rather than aerobatic training, the fact that the training can be overwhelming to some students, and scheduling each student in the program when the weather does not always cooperate. Each of these concerns is valid and in the ideal world each of these problems could be easily overcome, but when any type of training is completed there will always be room for improvement. As long as an organization is willing to attempt this type of training, the benefits will far outweigh the obstacles that are encountered.

After the variety of answers to how the programs can be improved, an attempt was made to determine what the benefits were to completing upset recovery training. In each program, student confidence and experience was determined to be the largest benefit from this type of training. At the start of this type of training, several students are understandably nervous or have a high degree of anxiety as to what lies ahead. After the completion of the training most students have more confidence in their normal flying skills and abilities as well as an understanding of what an airplane's capabilities are, based upon their experience in the upset program. 
Finally, a Likert Scale of 15, with 5 being the highest score, was used to determine the perceived effectiveness of the upset recovery training. Based upon the fact that the programs did what each school was striving towards, scores averaged 4.6. Several comments were made that the training that was being provided was an introduction to the concepts and ideas of upset recovery training, and in order to obtain a level of proficiency in advanced maneuvers and recoveries, more training would be necessary.

All of the schools were asked further questions about the types and levels of flight training that are provided in areas that approach upset recovery training. All of the schools surveyed accomplish unusual attitude training as required by the FARs for pilot certification, but this survey made a distinction between unusual attitudes and upset situations. Primarily the amount of pitch and bank separates an unusual attitude and an upset situation. The argument could be made that upset situations are essentially extreme unusual attitudes.

All of the schools complete spin training in an airplane for the certified flight instructor certificate as required by the FARs, but 5 of the schools that complete upset recovery training and 3 of the schools that do not complete upset recovery training deliver spin training as part of the commercial flight training. This type of training is a logical middle ground for those programs that want to do more than unusual attitudes, but cannot support a full upset recovery-training program. Furthermore, spin training is especially applicable to general aviation due to the higher probability of spins occurring in general aviation aircraft.

A question about formal classroom training was asked of every school that participated in the survey and the results were wide ranging. All of the schools that complete upset recovery training have a portion of the training in a classroom where accident statistics, various scenarios, and recovery techniques are discussed. One school offers a class for credit, which documents the history and theory behind upset recovery training while providing some instruction using commercially available computer flight simulators. The majority of the schools included this training in some other class. Some schools discussed upset scenarios while diagnosing accident data for human factors and accident investigation classes.

The final question asked of every school participating in the survey attempted to determine how important (Likert Scale 1 [not important] - 5 [very important]) upset recovery training was for preparing students for the aviation industry. For those schools providing upset recovery training the answer, not surprisingly, was a strong 5 in all cases with a couple of qualifiers stating only if the training is done properly. For those schools not providing upset recovery training the answers ranged from 3 to 5 with the average being 4.25 .

All of the questions and answers that were discussed in the previous section are displayed in Appendix A.

\section{DISCUSSION}

Upset recovery training is one area of aviation safety and accident prevention that does not receive a great deal of dedicated focus. Controlled flight into terrain (CFIT) and visual flight (VFR) into instrument meteorological conditions (IMC) have and continue to be at the center of the FAA's attention when it comes to accident prevention, but upset recovery training sometimes falls by the wayside. The fact that CFIT and VFR into IMC have more concrete cause and effect relationships and are more easily addressed has made these problems frequent subjects of accident prevention efforts. Given the number of variables involved in upset scenarios and the airplane and instructor requirements, this type of training presents some large obstacles.

The importance of upset recovery training in preparing students for the aviation industry is obvious when looking at the numbers for both schools that do and do not provide upset training. The decision to include or exclude an upset recovery program must nonetheless be based upon cost effectiveness. Every school must make resource allocation decisions based on the need to provide the best education possible for the students. If given the choice, the majority of the schools surveyed would provide upset recovery training but factors including equipment and instructor availability and money may dictate the decision. 
It is important to note that all of the schools providing upset recovery training in an airplane realize the importance of providing classroom training on the subject as well. Training in an airplane without the accompanying classroom portion lends itself more towards aerobatic rather than upset training. Where aerobatic training focuses primarily on the manipulation of flight controls to produce a specific flight path in structured patterns, upset recovery training focuses on recovery techniques from upset situations without predetermined flight patterns. In addition to those schools that provide training in an airplane, some of the schools that cannot, at this time, support a flight portion have dedicated portions of classroom lectures to the subject of upset scenarios or recovery techniques. Obviously, training in a classroom, followed by instruction in an airplane is the ideal situation, but some training, whether in a classroom or in an airplane, is better than no training at all.

\section{CONCLUSION}

Some consensus exists that upset recovery training is an important piece of the total instructional package. Among four-year schools engaged in flight training, a small but significant percentage include some elements of upset recovery training. Among those that do not, the costs involved as well as the equipment and instructional requirements present difficult obstacles for development of a program of this type. In view of the costs of flight training, these are difficult problems to overcome, regardless of the importance attached to such efforts.

Given the safety mantra repeated in the airline industry these days, however, one should expect that upset training will garner increased attention in the future. As with any new initiative, decisions must be made regarding content, effective training methods, and instructor qualifications. Few agreed upon standards exist for such training, and instructor qualifications are not well defined. Furthermore, as the FAA has little to say with respect to the subject of upset recovery, training departments and programs are reluctant to venture forth without support and agreement on the issues involved.
An open dialogue on the subject of upset recovery training, including the specific content, teaching methodology, and instructor qualifications, should begin immediately. Given that such training is considered important for the preparation of professional pilots, input from airline training personnel and those involved with safety should be part of the development process.

It is critical to the success of this initiative that relevant information on the subject of upset recovery be shared among flight training programs. Research and study in this area continues at the present, funded in part by the FAA. The findings and recommendations of these efforts will be important for both the development of collegiate upset recovery programs and aviation safety, in general 
Appendix A

\begin{tabular}{|c|c|}
\hline Questions & Answers \\
\hline $\begin{array}{l}\text { Is your program providing upset recovery training defined by pitch } \\
\text { attitudes in excess of } 30 \text { degrees nose high or nose low or bank angles in } \\
\text { excess of } 60 \text { degrees }\end{array}$ & $\begin{array}{l}\text { Yes }-9 \\
(30 \%)\end{array}$ \\
\hline $\begin{array}{l}\text { Does your program mandate such training } \\
\text { for all flight students? }\end{array}$ & $\begin{array}{ll}\text { Yes }-4 & \text { No }-5 \\
(44 \%) & (56 \%)\end{array}$ \\
\hline $\begin{array}{l}\text { If not, which students are required to } \\
\text { receive this training, or is it strictly } \\
\text { optional? }\end{array}$ & $\begin{array}{l}\text { The } 5 \text { schools stated it was } \\
\text { optional to help keep student } \\
\text { costs to a minimum }\end{array}$ \\
\hline $\begin{array}{l}\text { What airplane(s) are used for this } \\
\text { training? }\end{array}$ & $\begin{array}{l}\text { Extra } 300, \text { Aerobat, Super } \\
\text { Decathlon, DeHavilland } \\
\text { Chipmunk, Aerobatic } \\
\text { Bonanzas, Citabrias, Cap 10s, } \\
\text { Great Lakes Bi-wing }\end{array}$ \\
\hline $\begin{array}{c}\text { Only Answered by } \\
\text { programs providing upset }\end{array}$ & $\begin{array}{l}\text { Cost and Availability were } \\
\text { main factors }\end{array}$ \\
\hline $\begin{array}{l}\text { What specific training is required to } \\
\text { qualify instructors for this duty? }\end{array}$ & $\begin{array}{l}\text { Multi-layered based upon; } \\
\text { natural interest, seniority, past } \\
\text { training, experience, piloting } \\
\text { skill }\end{array}$ \\
\hline $\begin{array}{l}\text { What do you dislike about the current } \\
\text { method of Upset Recovery Training? }\end{array}$ & $\begin{array}{l}\text { Making training mandatory, } \\
\text { more in-depth training, more } \\
\text { student friendly, }\end{array}$ \\
\hline $\begin{array}{l}\text { What are the overall benefits to upset } \\
\text { recovery training? }\end{array}$ & $\begin{array}{l}\text { Increased student confidence } \\
\text { and experience }\end{array}$ \\
\hline $\begin{array}{l}\text { What is the perceived effectiveness (scale } \\
\text { of 1-5) of your Upset Recovery/Unusual } \\
\text { Attitude Training? }\end{array}$ & Average of 4.6 \\
\hline Do you complete spin training as part of the commercial certificate? & $\begin{array}{l}5 \text { of the schools that do and } \\
\text { that do not provide upset } \\
\text { recovery training complete spin } \\
\text { training during the commercial } \\
\text { certificate }\end{array}$ \\
\hline $\begin{array}{l}\text { How much formal classroom instruction is mandated on the subject of } \\
\text { upset training? }\end{array}$ & $\begin{array}{l}\text { All schools surveyed provide } \\
\text { some level of upset recovery } \\
\text { training. The levels provided } \\
\text { ranged from discussing this } \\
\text { training in conjunction with } \\
\text { accident investigation exercises } \\
\text { to a class for credit covering } \\
\text { upset recovery training entirely }\end{array}$ \\
\hline $\begin{array}{l}\text { How important (scale of 1-5) is Upset Recovery Training for preparing } \\
\text { students for the aviation industry? }\end{array}$ & $\begin{array}{l}9 \text { schools providing upset } \\
\text { recovery training }-5 \text { average } \\
21 \text { schools not providing upset } \\
\text { recovery training }-4.2 \text { average }\end{array}$ \\
\hline
\end{tabular}




\section{REFERENCES}

Aircraft Owners and Pilot Association - Air Safety Foundation (2002). 2001 Nall Report: General Aviation Accident Trends and Factors. Retrieved January 15, 2003, from www.aopa.org/asf/publications/01nall.pdf.

Air Line Pilots Association. (1998, June). Submission of the Air Line Pilo ts Association to the National Transportation Safety Board Regarding the Accident Involving Comair Flight 3272 at Monroe, MI on January 9, 1997(.7967 CMR 3272). Herndon, VA: Serber, M. L.

Airplane Safety Engineering. (1997, June). Statistical Summary of Commercial Jet Airplane Accidents, Worldwide Operations. 1959-1996. Seattle, Washington: Boeing Commercial Airplane Group

The Boeing Company. (1998). Aerodynamic Principles of Large-Airplane Upsets. Retrieved January 15, 2003, from http://www.boeing.com/commercial/aeromagazine/aero_03/textonly/fo01txt.html

The Boeing Company. (1998). Airplane Recovery Training Aid (MC 20-97). Seattle, Washington: Boeing Commercial Airplane Group.

Flight Safety Foundation Editorial Staff. (1993, March). Spatial Disorientation Linked to Fatal DC-8 Freighter Crash. Flight Safety Foundation Accident Prevention. Volume 50, Number 3.

Flight Safety Foundation Editorial Staff. (2001, Octo ber). Icing, Inadequate Airspeed Trigger Loss of Control of Saab 340. Flight Safety Foundation Accident Prevention. Volume 58, Number 10.

Lawton, R. (1994, November). Airframe Icing and Captain's Improper Use of Autoflight System Result in Stall and Loss of Control of Commuter Airplane. Flight Safety Foundation Accident Prevention. Volume 51, Number 11

Marsh, A. K. (1999, August). In-Flight Emergencies: Upset Recovery, Making the Most of a Bad Attitude. AOPA Pilot. http://www.aopa.org/pilot/features/inflight9908.html

Sands, J. (1999). Training Best Practices: What Are You Doing?. NBAA Digest. Volume 12, Number 6/7, Operations Notes. 
United States Department of Transportation, Federal Aviation Administration (USDOT, FAA). (2001). Table 7-aircraft departures scheduled and aircraft departures performed, by community, by air carrier, and by aircraft type 12 months ended December 31, 2000. Airport Activity Statistics of Certificated Route Air Carriers. Washington, D.C.: U.S. Government Printing Office.

United States Department of Transportation, Federal Aviation Administration (USDOT, FAA) Southern Region. (1999, November). Environmental impact statements. Airportopics. Retrieved June 10, 2001 from http://www.faa.gov/aso/aso600/airportopics/9911/index.htm.

United States Department of Transportation, Federal Aviation Administration (USDOT, FAA) Southern Region. (2000, April). DOT flagship initiatives. Retrieved June 21, 2001 from the FAA Southern Region Airport Division, Environmental Newsline, http://www.faa.gov/ aso/aso600/envnews/0004/dotflagship.htm, accessed June 21, 2001.

United States Department of Transportation, Federal Aviation Administration (USDOT, FAA). (2000, August 15). Environmental justice $q \& a$. Retrieved July 10, 2001 from Interim Policy Guidance, http://www.aee.faa.gov/ aee_200/ejq\&a.pdf.

United States Environmental Protection Agency (USEPA). (1992, June). Environmental equity: reducing risks for all communities volume 1. EPA Policy Planning and Evaluation Report No. PM-221. EPA230-R-92-008. Washington, DC.

United States Environmental Protection Agency (USEPA). (1999, June). Final guidance for consideration of environmental justice in clean air act 309 reviews. Retrieved June 10, 2001 from http://es.epa.gov/oeca/ofa/ej_nepa.html.

Weinberg, A. S. (1998, September). The environmental justice debate: new agendas for a third generation of research. Society and Natural Resources, 11(6), 605-614.

Whitehead, R., Jr. \& Merritt, R. (1999, August). Managing environmental justice risks. The CPA Journal, 69(8), 30-33.

Williams, R. W. (1999). The contested terrain of environmental justice research: community as unit of analysis. Social Science Journal, 36(2), 313-328.

Worsham, J. B. L. (2000). Disparate impact lawsuits under title VI, section 602: can a legal tool build environmental justice? Boston College Environmental Affairs Law Review, 27(4), 631-706.

Zimmerman, R. (1993). Social equity and environmental risk. Risk Analysis, 13(6), 649-666. Quoted in Liu, F. (2000). Environmental justice analysis. Boca Raton, Florida: Lewis Publishers. 


\section{Appendix A}

Figures

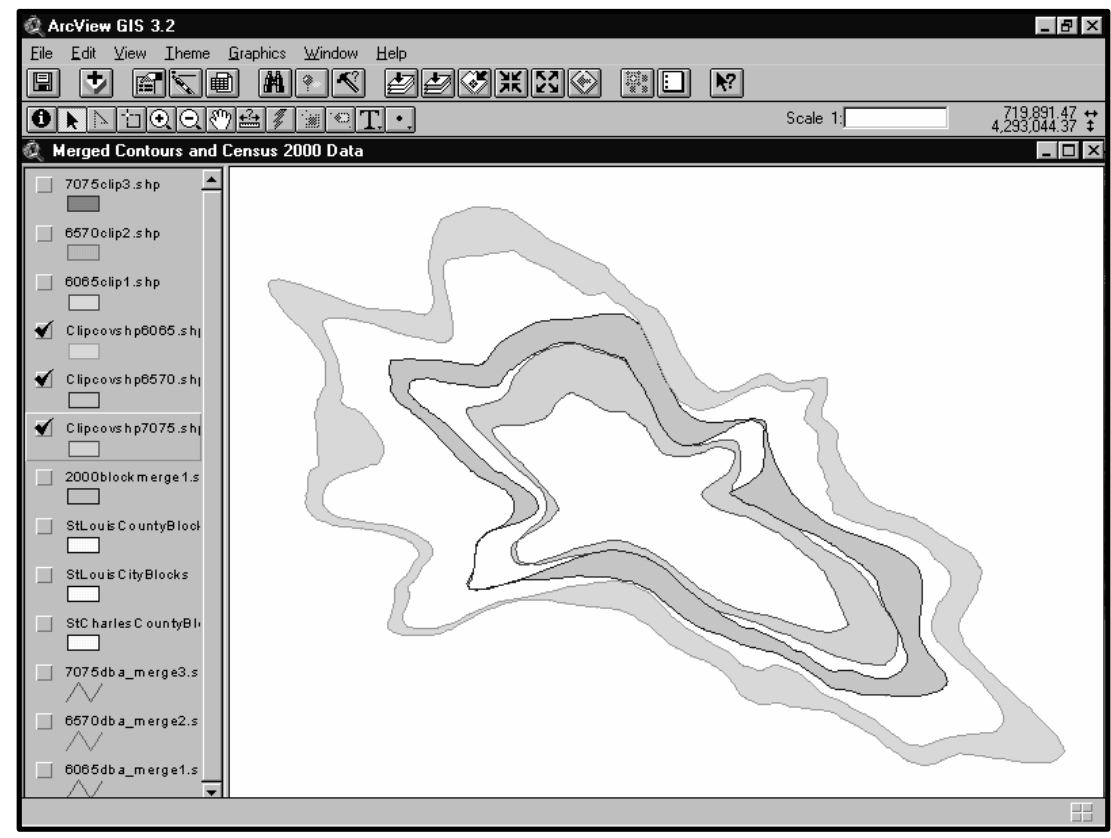

Figure 1 Composite INM noise contours for the period between 1990 and 2000.

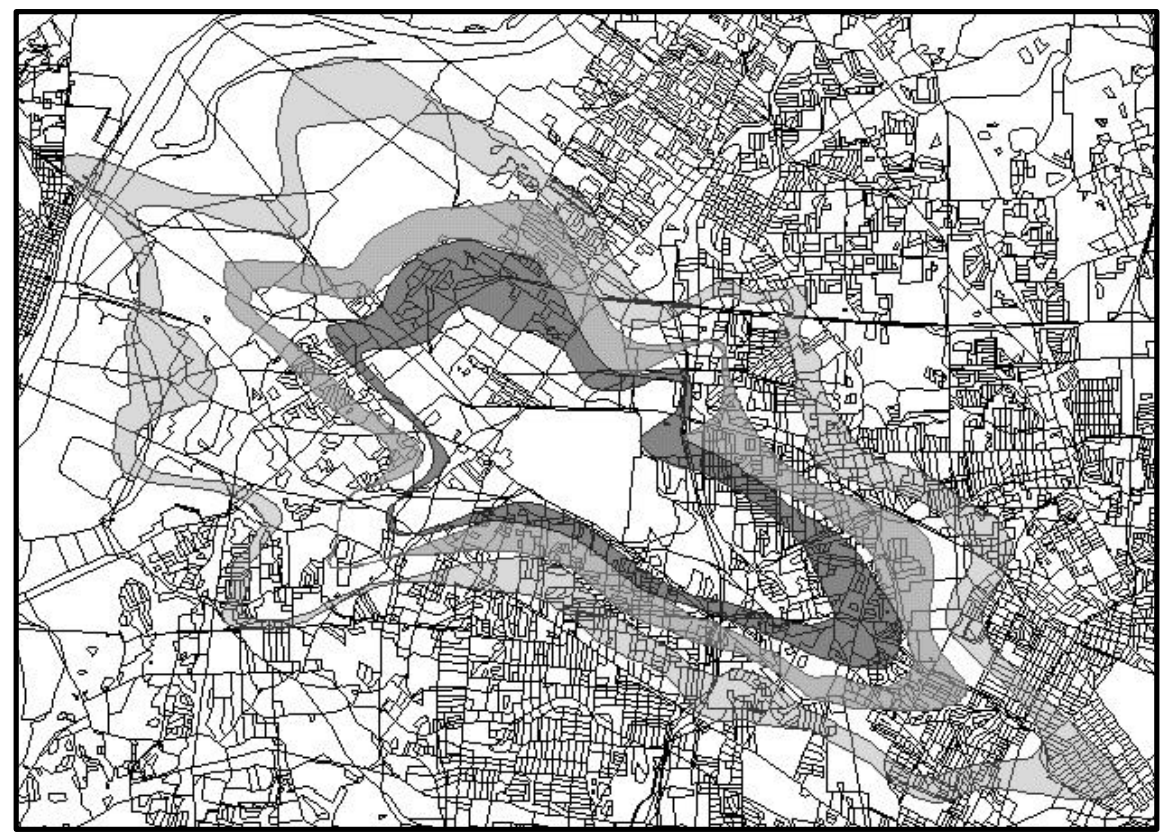

Figure 2 Contour composites geographically referenced to census blockgroups. 


\section{Appendix B}

Descriptive Statistics in Tabular Format

\begin{tabular}{|l|c|c|c|c|c|c|}
\hline $\begin{array}{l}\text { Demographic Units } \\
\text { and Column Totals }\end{array}$ & $\begin{array}{c}1990 \text { Total } \\
\text { Population }\end{array}$ & $\begin{array}{c}1990 \text { Non- } \\
\text { protected }\end{array}$ & $\begin{array}{c}1990 \\
\text { Protected }\end{array}$ & $\begin{array}{c}\text { 2000 Total } \\
\text { Population }\end{array}$ & $\begin{array}{c}2000 \text { Non- } \\
\text { Protected }\end{array}$ & $\begin{array}{c}2000 \\
\text { Protected }\end{array}$ \\
\hline \hline & & & & & & \\
\hline St. Louis City & 212,675 & 205,209 & 7,466 & 283,883 & 268,756 & 15,127 \\
\hline St. Louis County & 396,673 & 202,078 & 194,595 & 348,189 & 152,666 & 195,523 \\
\hline Subtotals & 609,348 & 407,287 & 202,061 & 632,072 & 421,422 & 210,650 \\
\hline Percentages & & $66.84 \%$ & $33.16 \%$ & & $66.67 \%$ & $33.33 \%$ \\
\hline \hline & & & & & & \\
\hline St. Charles County & 993,433 & 836,165 & 157,268 & $1,016,315$ & 780,830 & 235,485 \\
\hline Grand Total (3 Units) & $1,602,781$ & $1,243,452$ & 359,329 & $1,648,387$ & $1,202,252$ & 446,135 \\
\hline Percentages & & $77.58 \%$ & $22.42 \%$ & & $72.94 \%$ & $27.06 \%$ \\
\hline
\end{tabular}

Table 1. Reference population values (after Most et al., 2002).

\begin{tabular}{|l|c|c|c|c|c|c|}
\hline $\begin{array}{l}\text { 60-65dB Contour } \\
\text { Blockgroup Census } \\
\text { ID Number }\end{array}$ & $\begin{array}{c}1990 \\
\text { Total } \\
\text { Population }\end{array}$ & $\begin{array}{c}1990 \\
\text { Non- } \\
\text { Protected }\end{array}$ & $\begin{array}{c}1990 \\
\text { Protected } \\
\text { Population }\end{array}$ & $\begin{array}{c}2000 \\
\text { Total } \\
\text { Population }\end{array}$ & $\begin{array}{c}2000 \\
\text { Non- } \\
\text { Protected }\end{array}$ & $\begin{array}{c}2000 \\
\text { Protected } \\
\text { Population }\end{array}$ \\
\hline \hline $1072.00-3$ & 552 & 27 & 525 & 529 & 6 & 523 \\
\hline $1074.00-4$ & 1176 & 14 & 1162 & 756 & 10 & 746 \\
\hline $1074.00-5$ & 872 & 28 & 844 & 598 & 17 & 581 \\
\hline $1074.00-6$ & 854 & 17 & 837 & 577 & 12 & 565 \\
\hline Totals & 3454 & 86 & 3368 & 2460 & 45 & 2415 \\
\hline Percentages & $2.49 \%$ & $97.51 \%$ & & $1.83 \%$ & $98.17 \%$ \\
\hline \hline \multicolumn{7}{|l|}{} \\
\hline 70-75dB Contour & 1990 & 1990 & 1990 & 2000 & 2000 & 2000 \\
Blockgroup Census & Total & $\begin{array}{c}\text { Non- } \\
\text { ID Number }\end{array}$ & $\begin{array}{c}\text { Protected } \\
\text { Population }\end{array}$ & $\begin{array}{c}\text { Total } \\
\text { Protected }\end{array}$ & $\begin{array}{c}\text { Non- } \\
\text { Population }\end{array}$ & $\begin{array}{c}\text { Population } \\
\text { Protected }\end{array}$ \\
\hline Population \\
\hline \hline $2114.01-3$ & 2876 & 2685 & 191 & 2784 & 2311 & 473 \\
\hline $2137.00-1$ & 797 & 244 & 553 & 674 & 130 & 544 \\
\hline Totals & 3673 & 2929 & 744 & 3458 & 2441 & 1017 \\
\hline Percentages & $79.74 \%$ & $20.26 \%$ & & $70.59 \%$ & $29.41 \%$ \\
\hline
\end{tabular}

Table 2. Within analysis results (after Most et al., 2002). 


\begin{tabular}{|c|c|c|c|c|c|c|}
\hline $\begin{array}{l}\text { 60-65dB Contour } \\
\text { (101 Blockgroups) }\end{array}$ & $\begin{array}{l}1990 \text { Total } \\
\text { Population }\end{array}$ & $\begin{array}{l}1990 \text { Non- } \\
\text { Protected }\end{array}$ & $\begin{array}{c}1990 \\
\text { Protected }\end{array}$ & $\begin{array}{l}2000 \text { Total } \\
\text { Population }\end{array}$ & $\begin{array}{l}2000 \text { Non- } \\
\text { Protected }\end{array}$ & $\begin{array}{c}2000 \\
\text { Protected }\end{array}$ \\
\hline Totals & 130,535 & 89,175 & 41,360 & 121,398 & 68,444 & 52,954 \\
\hline Percentages & & $68.32 \%$ & $31.68 \%$ & & $56.38 \%$ & $43.62 \%$ \\
\hline 70-75dB Contour & 1990 Total & 1990 Non- & 1990 & 2000 Total & 2000 Non- & 20004 \\
\hline (40 Blockgroups) & Population & Protected & Protected & Population & Protected & Protected \\
\hline Totals & 61,975 & 42,360 & 19,615 & 53,797 & 30,452 & 23,345 \\
\hline Percentages & & $68.35 \%$ & $31.65 \%$ & & $56.61 \%$ & $43.39 \%$ \\
\hline
\end{tabular}

Table 3. Adjacency analysis results (after Most et al., 2002).

\begin{tabular}{|l|c|c|c|c|c|c|}
\hline $\begin{array}{l}\text { 60-65dB Contour } \\
\text { (101 Blockgroups) }\end{array}$ & $\begin{array}{c}\text { 1990 Total } \\
\text { Population }\end{array}$ & $\begin{array}{c}\text { 1990 Non- } \\
\text { Protected }\end{array}$ & $\begin{array}{c}1990 \\
\text { Protected }\end{array}$ & $\begin{array}{c}\text { 2000 Total } \\
\text { Population }\end{array}$ & $\begin{array}{c}\text { 2000 Non- } \\
\text { Protected }\end{array}$ & $\begin{array}{c}2000 \\
\text { Protected }\end{array}$ \\
\hline \hline Totals & 39,869 & 23,582 & 16,286 & 36,596 & 17,899 & 18,697 \\
\hline Percentages & & $59.15 \%$ & $40.85 \%$ & & $48.91 \%$ & $51.09 \%$ \\
\hline \hline \multicolumn{7}{|l|l|}{} \\
\hline 70-75dB Contour & 1990 Total & 1990 Non- & 1990 & 2000 Total & 2000 Non- & 2000 \\
(40 Blockgroups) & Population & Protected & Protected & Population & Protected & Protected \\
\hline \hline Totals & 16,946 & 11,149 & 5,798 & 15,059 & 7,792 & 7,266 \\
\hline Percentages & & $65.79 \%$ & $34.21 \%$ & & $51.75 \%$ & $48.25 \%$ \\
\hline
\end{tabular}

Table 4. Areal interpolation results (after Most et al., 2002).

\begin{tabular}{|c|c|c|c|c|c|c|}
\hline $\begin{array}{l}\text { 60-65dB Contour } \\
\text { (101 Blockgroups) }\end{array}$ & $\begin{array}{l}1990 \text { Total } \\
\text { Population }\end{array}$ & $\begin{array}{l}1990 \text { Non- } \\
\text { Protected }\end{array}$ & $\begin{array}{c}1990 \\
\text { Protected }\end{array}$ & $\begin{array}{l}2000 \text { Total } \\
\text { Population }\end{array}$ & $\begin{array}{l}2000 \text { Non- } \\
\text { Protected }\end{array}$ & $\begin{array}{c}2000 \\
\text { Protected }\end{array}$ \\
\hline Totals & 1919,661 & 879 & 1818,782 & 1717,992 & 221 & 1717,770 \\
\hline Percentages & & $4.47 \%$ & $95.53 \%$ & & $1.23 \%$ & $98.77 \%$ \\
\hline 70-75dB Contour & 1990 Total & 1990 Non- & 1990 & 2000 Total & 2000 Non- & 2000 \\
\hline 40 Blockgroups & Population & Protected & Protected & Population & Protected & Protected \\
\hline Totals & 10,799 & $5,5,111$ & $5,5,688$ & 9,484 & 3 & $5,5,881$ \\
\hline Percentages & & $47.32 \%$ & $52.68 \%$ & & $37.99 \%$ & $62.01 \%$ \\
\hline
\end{tabular}

Table 5. Cross-area transformation results (after Most et al., 2002). 